\title{
Factors Related To Examination of IVA In Reproductive Women
}

\author{
Laila Fitri $^{1}$; Hellen Febriyanti²; Riona Sanjaya ${ }^{\left.3^{*}\right)}$
}

Published online:5 June 2021

\begin{abstract}
Absract
Cervical cancer is a cancer that occurs in the cervix, which is the area of the female reproductive organ which is the entrance to the uterus, located between the uterus (uterus) and the female intercourse (vagina). The incidence of cervical cancer can be detected by the method of Visual Inspection of Acetic Acid (IVA), the IVA examination aims to find pre-cancerous cervical lesions before they become cancerous. The research objective is to know the factors associated with IVA examination in fertile-aged women couples in the work area of Karya Tani Labuhan Maringgai Health Center, East Lampung Regency in 2021. This type of quantitative research with cross sectional approach. The population of this study were all WUS III with a sample of 98 respondents. the object of this research is the IVA examination. The research was conducted in the work area of Karya Tani Labuhan Maringgai Community Health Center, East Lampung Regency in April 2021. Data collection used a questionnaire. Univariate and bivariate (chi square) data analysis. The results showed that there was a relationship between knowledge and IVA examination in the work area of the Karya Tani Labuhan Maringgai Community Health Center in East Lampung Regency in 2021 (pvalue $=0.018, \mathrm{OR}=6,000$ ). There is a socio-cultural relationship to IVA examination in the work area of Karya Tani Labuhan Maringgai Health Center, East Lampung Regency in 2021 ( $\mathrm{p}$-value $=0.002$, OR = 7.333). There is a relationship between family / husband support for IVA examination in the work area of the Karya Tani Labuhan Maringgai Community Health Center, East Lampung Regency in 2021 (p-value 0.004, OR = 5.760). There is no relationship between health care workers' support for IVA examinations in the work area of Karya Tani Labuhan Maringgai Community Health Center, East Lampung Regency in 2021 (p-value $=0.383$ ). Suggestions to IVA officers are expected to take a personal approach to women of reproductive age couples so that they want to do IVA examinations
\end{abstract}

Keywords: IVA, Knowledge, Husband / Family Support, Health Officer Support, Socio-Culture, WUS

\section{PENDAHULUAN}

Kanker serviks adalah tumor ganas yang tumbuh di daerah leher rahim (serviks). Kanker serviks merupakan keganasan yang paling banyak ditemukan di negara berkembang begitu juga di Indonesia menduduki peringkat satu. Umumnya kanker serviks sekitar 70\% datang dengan kondisi stadium lanjut (Kurnaesih, E; LIndasari, S.W; Asrina, 2018). Kejadian kanker serviks dapat dideteksi dengan metode Inspeksi Visual Asam Asetat (IVA), pemeriksaan IVA bertujuan untuk menemukan lesi pra kanker leher rahim, sebelum menjadi kanker. Metode inspeksi visual lebih mudah, lebih sederhana dan lebih mampu terlaksana. Metode ini dapat dilakukan di semua

\footnotetext{
1,2,3 Universitas Aisyah Pringsewu

*) corresponding author
}

Riona Sanjaya

Program Studi Kebidanan Program Sarjana Terapan Fakultas Kesehatan Universitas Aisyah Pringsewu Email: riona2212@gmail.com tingkat pelayanan kesehatan oleh petugas kesehatan yang terlatih (Ardayani, Tinggi, Kesehatan, \& Bandung, 2020). Skrining IVA efektif memberikan kontribusi untuk menurunkan mortalitas dan morbiditas yang terkait dengan keganasan kanker serviks (Kurnaesih, E; LIndasari, S.W; Asrina, 2018).

Kanker serviks merupakan kanker paling sering keempat pada wanita dengan perkiraan 530.000 kasus baru, yang mewakili 7,9\% dari semua kanker wanita. Perkiraan American Cancer Society untuk kanker serviks di Amerika Serikat untuk tahun 2018 adalah sekitar 13.240 kasus baru kanker serviks invasif (Arbyn et al., 2020). Sekitar 4.170 wanita akan meninggal akibat kanker serviks. diperkirakan 930 kasus baru kanker serviks akan didiagnosis di Australia. Di Hongkong, kanker serviks adalah kanker ketujuh yang paling umum di antara wanita dengan 500 kasus baru di tahun 2015, menyumbang 3,3\% dari semua kasus kanker baru pada wanita (Jumaida, Sunarsih, Rosmiyati, \& Hermawan, 2020).

Tahun 2019 telah ditemukan 84.1859 IVA positif, 28.910 tumor payudara, 5.015 curiga kanker leher rahim, dan 2.910 curiga kanker payudara. Provinsi dengan cakupan deteksi dini tertinggi adalah Sulawesi Barat sebesar 104,2\%, diikuti oleh Kep. Bangka Belitung sebesar 
51,3\%, dan Sulawesi Selatan sebanyak 39\%. Sedangkan provinsi dengan cakupan deteksi dini terendah adalah Papua sebesar 0,9\%, Sulawesi Tenggara sebesar $1,7 \%$, dan Aceh sebesar 2,6\% dan untuk Provinsi Lampung sebesar 23,4\% (Kemenkes RI, 2020).

Cakupan pemeriksaan deteksi dini kanker leher rahim dan payudara pada perempuan usia 30-50 tahun tertinggi berada di Kota Bandar Lampung yaitu sebesar 24,2\% diikuti Kabupaten Tulang Bawang sebesar 10,5\% dan Way Kanan sebesar $8,2 \%$ sedangkan Kabupaten Lampung Timur sebesar 2,7\% masuk dalam lima terendah pemeriksaan IVA (Dinas Kesehatan Provinsi Lampung, 2020).

Rendahnya cakupan deteksi dini merupakan salah satu alasan makin berkembangnya kanker serviks. Hal ini berdasarkan fakta lebih dari 50\% perempuan yang terdiagnosis kanker tidak pernah menjalani deteksi dini sebelumnya (Wulandari, Wahyunigsih, \& Yunita, 2018). Kanker serviks dapat dikenali pada tahap pra kanker, salah satunya dengan melakukan pemeriksaan skrining seperti pap smear, kolposkopi atau tes IVA, dari seluruh pemeriksaan deteksi dini kanker serviks, tes IVA merupakan salah satu pemeriksaan yang dilakukan secara sederhana (Endang Mayasari, 2017). Melakukan skrining perlu adanya perilaku wanita yang taat dan patuh dalam pelaksanaan pemeriksaan. Pada teori Lawrence Green menyatakan perilaku ditentukan dan terbentuk melalui 3 faktor, yaitu faktor predisposisi yang termasuk (pengetahuan, sikap, kepercayaan, keyakinan, nilai nilai), faktor pendukung yang termasuk (lingkungan fisik, seperti tersedianya fasilitas kesehatan) dan faktor pendorong yang termasuk (sikap dan perilaku petugas kesehatan atau petugas lain) (Pebrina, Kusmiyanti, \& Surianto, 2019).

Faktor sikap, tingkat pendidikan, tingkat pengetahuan, peran kader, penyuluhan kesehatan dan dukungan anggota keluarga berpengaruh terhadap perilaku pemeriksaan IVA. Faktor yang paling dominan menentukan perilaku IVA secara berurutan adalah tingkat pendidikan $(\mathrm{OR}=3,403)$, sedangkan factor lainnya sebagai factor protektif meliputi akses informasi $(\mathrm{OR}=0,272)$, peran petugas kesehatan $(\mathrm{OR}=0,163)$, sikap $(\mathrm{OR}=0,104)$ dan penghasilan WUS (OR=0,045) (Wulandari et al., 2018).

Pemeriksaan IVA pada WUS / WUS merupakan peluang yang baik dalam upaya mencegah kanker serviks. Namun dari hasil wawancara awal diketahui bahwa berbagai faktor dapat mempengaruhi pemeriksaan tes IVA. Berdasarkan hasil kajian dokumentasi yang dilakukan oleh peneliti di rekam medis Puskesmas Karya Tani diketahui bahwa pada tahun 2018 jumlah WUS sebanyak 3590 dan yang melakukan pemeriksaan IVA sebanyak 247 dengan hasil IVA positif sebanyak 10 dan dicurigai kanker serviks sebanyak 1 orang. Tahun 2019 WUS sebanyak 3604 yang melakukan pemeriksaan IVA sebanyak 277 orang dengan hasil pemeriksaan IVA positif sebanyak 12 dan di curigai mengalami kanker servik sebanyak 2 orang.

Berdasarkan hasil prasurvey yang dilakukan dari tanggal 11 - 17 Oktober 2020 dengan wawancara tidak terstruktur yang dilakukan peneliti melalui wawancara kepada 25 orang wanita usia subur (WUS) atau wanita Pasangan Usia Subur (PUS). Dari hasil wawancara mengatakan bahwa 21(84\%) WUS tersebut tidak melakukan pemeriksaan IVA dengan alasan karena merasa tidak memiliki faktor resiko, takut dengan hasil test, merasa takut dengan pandangan negatif jika melakukan test, merasa malu jika ketahui hasil test positif, tidak diijinkan suami. Sedangkan $4(16 \%)$ orang Ibu lainnya melakukan pemeriksaan dikarenakan mengikuti anjuran tenaga kesehatan, merasa memiliki resiko kanker serviks.

\section{METODE PENELITIAN}

Jenis penelitian yang digunakan dalam penelitian ini adalah penelitian kuantitatif adalah metode penelitian yang dapat diartikan sebagai metode yang berlandaskan pada filsafat positifisme digunakan untuk meneliti pada populasi atau sampel tertentu, pengumpulan data menggunakan instrumen penelitian analisis data bersifat kuantitatif dengan tujuan untuk menguji hipotesis yang telah ditetapkan (Sugiyono, 2018). Rancangan penelitian menggunakan pendekatan Cross-sectional (pendekatan silang) yaitu penelitian yang di adakan dalam waktu yang bersamaan tetapi dengan subjek yang berbeda-beda (Notoatmodjo, 2018).

Penelitian ini telah dilakukan di wilayah kerja Puskesmas Karya Tani Labuhan Maringgai Kabupaten Lampung Timur pada bulan April Tahun 2021.

Populasi adalah keseluruhan objek penelitian atau objek yang diteliti (Notoadmojo, 2018). Sesuai dengan tujuan yang ingin dicapai, populasi pada penelitian ini adalah seluruh WUS yang ada di wilayah kerja Puskesmas, dimana berdasarkan data terakhir jumlah WUS sebanyak 3604. Besar sampel diambil dengan menggunakan rumus besar sampel dari seluruh populasi, dengan menghitung besarnya untuk mengukur proporsi dengan derajat akurasi pada tingkat statistik yang bermakna (significance), menggunakan formula sederhana.

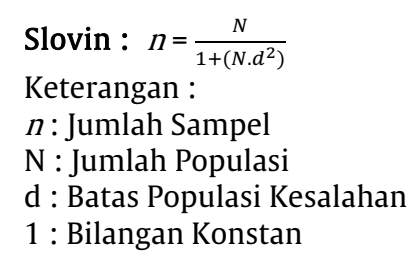

Pada penelitian ini jumlah populasi yaitu sebanyak 3604 orang,maka sampel yang digunakan yaitu :

$$
\begin{aligned}
& n=\frac{3604}{1+(3604 \times 0,01)} \\
& n=97,3 \text { di bulatkan menjadi } 98 \\
& \text { Jumlah sampel minimal adalah } 98 \text { responden }
\end{aligned}
$$

Cara Pengambilan sampel metode purposive sampling di mana peneliti dalam memilih sampel sesuai dengan cara menetapkan ciri-ciri khusus yang sesuai dengan tujuan penelitian sehingga diharapkan dapat menjawab permasalahan penelitian (Notoatmodjo, 2012). Pada penelitian ini, peneliti mengidentifikasi sampel yang akan digunakan adalah semua wanita usia subur (WUS), untuk mempermudah pengambilan sampel dan ketepatan dalam pengambilan sampel (Notoatmodjo, 2018).

\section{Kriteria inkulsi:}

1. Ibu yang bersedia menjadi responden

2. Perempuan berusia 30-50 tahun

3. Perempuan yang melakukan hubungan seksual secara aktif.

4. Memiliki Suami.

Kriteria eksklusi:

1. Menderita kanker serviks.

2. Sedang keadaan hamil.

Variabel yang digunakan dalam penelitian ini yaitu pemeriksaan tes IVA pada WUS dan pengetahuan, sosial budaya, dukungan suami, peran petugas kesehatan. 
Alat ukur yang digunakan berupa lembar kuesioner. Analisa penelitian yang digunakan yaitu analisis univarit dan bivariat.

\section{HASIL PENELITIAN}

Tabel 1

Distribusi Frekuensi Pemeriksaan IVA

\begin{tabular}{|c|c|c|c|}
\hline Variabel & Kategori & $\mathbf{N}$ & $\%$ \\
\hline \multirow{2}{*}{ Pemeriksaan IVA } & Melakukan Pemeriksaan IVA & 14 & 14,3 \\
\hline & Tidak Melakukan Pemeriksaan IVA & 84 & 85,7 \\
\hline \multirow{2}{*}{ Pengetahuan } & Baik & 54 & 55,1 \\
\hline & Kurang Baik & 44 & 44,9 \\
\hline \multirow{2}{*}{ Sosial Budaya } & Positif & 39 & 39,8 \\
\hline & Negatif & 59 & 60,2 \\
\hline \multirow{2}{*}{ Dukungan Keluarga/Suami } & Positif & 29 & 29,6 \\
\hline & Negatif & 69 & 70,4 \\
\hline \multirow{2}{*}{ Peran Petugas Kesehatan } & Positif & 57 & 58,2 \\
\hline & Negatif & 41 & 41,8 \\
\hline Total & & 98 & 100,0 \\
\hline
\end{tabular}

Berdasarkan tabel 1 terlihat bahwa distribusi frekuensi responden tidak melakukan pemeriksaan IVA yaitu sebanyak $84(85,7 \%)$ responden, pengetahuan baik sebanyak $54(55,1 \%)$ responden, sosial budaya negatif sebanyak 59 (60,2\%) responden, Dukungan Keluarga/Suami negatif sebanyak 69 (70,4\%) responden, Dukungan Petugas positif sebanyak $57(58,2 \%)$ responden.

Tabel 2

Hubungan Pengetahuan Dengan Pemeriksaan IVA

\begin{tabular}{|c|c|c|c|c|c|c|c|c|}
\hline \multirow{3}{*}{ Pengetahuan } & \multicolumn{4}{|c|}{ Pemeriksaan IVA } & \multicolumn{2}{|c|}{ Jumlah } & \multirow[t]{3}{*}{ P-Value } & \multirow[t]{2}{*}{$\begin{array}{c}\text { OR } \\
95 \% \mathrm{CI} \\
\end{array}$} \\
\hline & \multicolumn{2}{|c|}{ Melakukan } & \multicolumn{2}{|c|}{ Tidak Melakukan } & & & & \\
\hline & $\mathrm{n}$ & $\%$ & $\mathbf{n}$ & $\%$ & $\mathbf{N}$ & $\%$ & & \\
\hline Baik & 12 & 22,2 & 42 & 77,8 & 54 & 100,0 & & 6,000 \\
\hline Kurang baik & 2 & 4,5 & 42 & 95,5 & 44 & 100,0 & $\begin{array}{r}0 \\
018\end{array}$ & $(1,265-$ \\
\hline Jumlah & 14 & 14,3 & 84 & 85,7 & 98 & 100,0 & & $28,463)$ \\
\hline
\end{tabular}

Berdasarkan tabel 2 diketahui bahwa dari 54 responden dengan pengetahuan baik, sebanyak $12(22,2 \%)$ responden melakukan pemeriksaan IVA dan sebanyak 42 (77,8\%) responden tidak melakukan pemeriksaan IVA. Dari 44 responden dengan pengetahuan kurang baik, sebanyak 2 $(4,5 \%)$ responden melakukan pemeriksaan IVA dan sebanyak $42(95,5 \%)$ responden tidak melakukan pemeriksaan IVA. Hasil uji statistik diperoleh $p$-value $=$ 0,018 yang berarti $p>\alpha=0,05$ (Ha diterima dan Ho ditolak), maka dapat disimpulkan bahwa ada hubungan pengetahuan terhadap pemeriksaan IVA di wilayah kerja Puskesmas Karya Tani Labuhan Maringgai Kabupaten Lampung Timur Tahun 2021. Dengan nilai 6,000 berarti responden dengan pengetahuan baik memiliki peluang 6,000 lebih besar untuk melakukan pemeriksaan IVA jika dibandingkan dengan responden dengan pengetahuan kurang baik.

Tabel 3

Hubungan Dukungan Suami dengan Pemeriksaan IVA

\begin{tabular}{|c|c|c|c|c|c|c|c|c|}
\hline \multirow{3}{*}{$\begin{array}{l}\text { Dukungan } \\
\text { Keluarga/Suami }\end{array}$} & \multicolumn{6}{|c|}{ Pemeriksaan IVA } & \multirow{3}{*}{ P-Value } & \multirow{3}{*}{$\begin{array}{l}\text { OR } \\
95 \% \mathrm{CI}\end{array}$} \\
\hline & \multicolumn{2}{|c|}{ Melakukan } & \multicolumn{2}{|c|}{ Tidak Melakukan } & \multicolumn{2}{|c|}{ Jumlah } & & \\
\hline & $\mathrm{n}$ & $\%$ & $\mathrm{n}$ & $\%$ & $\mathrm{~N}$ & $\%$ & & \\
\hline Positif & 9 & 31,0 & 20 & 69,0 & 29 & 100,0 & \multirow{3}{*}{0,004} & \multirow{3}{*}{$\begin{array}{l}5,760 \\
(1,730 \\
19,181\end{array}$} \\
\hline Negatif & 5 & 7,2 & 64 & 92,8 & 69 & 100,0 & & \\
\hline Jumlah & 14 & 14,3 & 84 & 85,7 & 98 & 100,0 & & \\
\hline
\end{tabular}

Berdasarkan tabel 3 diketahui bahwa dari 29 responden dengan dukungan keluarga/suami positif, sebanyak 9 $(31,0 \%)$ responden melakukan pemeriksaan IVA dan sebanyak $20 \quad(69,0 \%)$ responden tidak melakukan pemeriksaan IVA. Dari 69 responden dengan dukungan keluarga/suami negatif, sebanyak 5 (7,2\%) responden melakukan pemeriksaan ibu hamil dan sebanyak 64 $(92,8 \%)$ responden tidak melakukan pemeriksaan IVA. Hasil uji statistik diperoleh $p$-value $=0,004$ yang berarti $\mathrm{p}>\alpha=$
0,05 (Ha diterima dan Ho ditolak), maka dapat disimpulkan bahwa ada hubungan dukungan keluarga/suami terhadap pemeriksaan IVA di wilayah kerja Puskesmas Karya Tani Labuhan Maringgai Kabupaten Lampung Timur Tahun 2021. Dengan nilai OR 5,760 berarti responden dengan dukungan keluarga/suami positif memiliki peluang 5,760 kali lebih besar untuk melakukan IVA jika dibandingkan dengan responden dengan dukungan keluarga/suami negatif.

\section{Tabel 4}

Hubungan Dukungan peran petugas dengan Pemeriksaan IVA 


\begin{tabular}{|c|c|c|c|c|c|c|c|c|}
\hline \multirow{3}{*}{$\begin{array}{c}\text { Dukungan Petugas } \\
\text { Kesehatan }\end{array}$} & \multicolumn{4}{|c|}{ Pemeriksaan IVA } & \multirow{2}{*}{\multicolumn{2}{|c|}{ Jumlah }} & \multirow{3}{*}{ p-value } & \multirow{3}{*}{ OR $95 \% \mathrm{CI}$} \\
\hline & \multicolumn{2}{|c|}{ Melakukan } & \multicolumn{2}{|c|}{ Tidak Melakukan } & & & & \\
\hline & $\mathrm{n}$ & $\%$ & $\mathrm{n}$ & $\%$ & $\mathbf{N}$ & $\%$ & & \\
\hline Positif & 10 & 17,5 & 47 & 82,5 & 57 & 100,0 & & \\
\hline Negatif & 4 & 9,8 & 37 & 90,2 & 41 & 100,0 & 0,383 & $1,968(0,571-6,780)$ \\
\hline Jumlah & 14 & 14,3 & 84 & 85,7 & 98 & 100,0 & & \\
\hline
\end{tabular}

Berdasarkan tabel 4 diatas diketahui bahwa dari 57 responden dengan dukungan petugas kesehatan positif, sebanyak $10(17,5 \%)$ responden melakukan pemeriksaan IVA dan sebanyak 47 (82,5\%) responden tidak melakukan pemeriksaan IVA. Dari 41 responden dengan dukungan petugas kesehatan negatif, sebanyak $4(9,8 \%)$ responden melakukan pemeriksaan IVA dan sebanyak 37 (90,2\%) responden tidak melakukan pemeriksaan IVA. Hasil uji statistik diperoleh $p$-value $=0,383$ yang berarti $\mathrm{p}<\alpha=0,05$ (Ho diterima dan Ha ditolak), maka dapat disimpulkan bahwa tidak ada hubungan antara dukungan petugas kesehatan terhadap pemeriksaan IVA di wilayah kerja Puskesmas Karya Tani Labuhan Maringgai Kabupaten Lampung Timur Tahun 2021.

\section{PEMBAHASAN}

\section{Pemeriksaan IVA}

Berdasarkan hasil penelitian dapat dilihat responden yang melakukan pemeriksaan IVA sebanyak 14 (14,3\%) responden lebih sedikit jika dibandingkan dengan responden yang tidak melakukan pemeriksaan IVA yaitu sebanyak $84(85,7 \%)$ responden.

Menurut Kemenkes (2010) hanya sebagian kecil dari perempuan yang menjalani dan mendapatkan hasil tes Pap juga menjalani evaluasi dan pengobatan yang semestinya bila ditemukan abnormalitas. Sebagai konsekuensinya, angka insidens kanker leher rahim tetap tinggi dan kebanyakan pasien datang pada stadium lanjut. Masalah yang berkembang akibat keterbatasan metode tes Pap inilah yang mendorong banyak penelitian untuk mencari metode alternatif skrining kanker leher rahim. Salah satu metode yang dianggap dapat dijadikan alternatif adalah metode inspeksi visual dengan asam asetat (IVA).

Penelitian yang dilakukan Sepa (2015) dengan judul Pengaruh Penyuluhan Kanker Serviks Terhadap Minat Pemeriksaan Pap Smear Pada Ibu Usia 20-60 Tahun Di Dusun Ngangkrik Triharjo Sleman Tahun 2015, diperoleh hasil sebelum penyuluhan minat pemeriksaan pap smear dalam kategori kurang, setelah penyuluhan diberikan minat dalam kategori baik. Ada beda pretest-postest 10,63 $(p=0,000)$

Menurut pendapat peneliti untuk mengurangi morbiditas atau mortalitas dari penyakit dengan pengobatan dini terhadap kasus-kasus yang ditemukan. Untuk mengetahui kelainan yang terjadi pada leher rahim.

\section{Pengetahuan}

Berdasarkan hasil penelitian diketahui pengetahuan kurang baik sebanyak $44(44,9 \%)$ responden lebih sedikit jika dibandingkan dengan pengetahuan responden yang baik yaitu sebanyak $54(55,1 \%)$ responden.

Sejalan dengan teori Notoatmodjo (2012), pengetahuan adalah merupakan hasil dari tahu dan ini setelah orang melakukan penginderaan terhadap obyek tertentu. Penginderaan terjadi melalui panca indera manusia, yakni indera penglihatan, pendengaran, penciuman, rasa dan raba. Sebagaian besar pengetahuan manusia diperoleh melalui mata dan telinga.Dari beberapa pengertian pengetahuan di atas dapat disimpulkan bahwa pengetahuan merupakan segala sesuatu yang diketahui yang diperoleh dari persentuhan panca indera terhadap objek tertentu. Pengetahuan pada dasarnya merupakan hasil dari proses melihat, mendengar, merasakan, dan berfikir yang menjadi dasar manusia dan bersikap dan bertindak.

Penelitian ini sejalan dengan penelitian yang dilakukan oleh Dewi (2013) dengan Hubungan Tingkat Pengetahuan Dan Sikap Wanita Usia Subur (WUS) Dengan Pemeriksaan Inspeksi Visual Asam Asetat (IVA) Di Puskesmas Buleleng I. Hasil penelitian ini didapatkan pengetahuan WUS $(\mathrm{p}=0,007)$.

Menurut pendapat peneliti oengetahuan merupakan hasil tahu yang terjadi setelah orang melakukan fungsifungsi pengindraan terhadap suatu kajian tertentu. Proses tersebut terjadi melalui penglihatan, pendengaran, penciuman, rasa dan perabaan. Pengetahuan yang kurang tentang suatu objek mengakibatkan kurangnya pemahaman tentang objek tersebut, sehingga bila seseorang tidak mengetahui mengenai posbindu maka akan mengakibatkan kurangnya pemahaman dalam pemanfaatan posbindu. Kurangnya pengetahuan akan mengakibatkan dampak yang kurang baik dalam pemeliharaan kesehatannya, sehingga menurunkan derajat kesehatan seseorang, dengan dilakukan pemeriksaan rutin akan mendeteksi kemungkinan penyakit yang diderita sehingga terhindar dari salah satu penyakit seperti; kanker rahim.

\section{Budaya}

Berdasarkan hasil penelitian diketahui responden yang memiliki budaya negatif sebanyak 59 (60,2\%) responden lebih banyak jika dibandingkan dengan responden yang memiliki budaya positif yaitu sebanyak 39 (39,8\%) responden.

Budaya, kultur atau kebudayaan adalah cara atau sikap hidup manusia dalam berhubungan secara timbal balik dengan alam dan lingkungan hidupnya yang didalamnya sudah tercakup pula segala hasil dari cipta, rasa, karsa, dan karya, baik yang fisik materiil maupun yang psikologis, idiil, dan spiritual.

Penelitian ini sejalan dengan penelitian yang dilakukan Sepa (2015) dengan judul Pengaruh Penyuluhan Kanker Serviks Terhadap Minat Pemeriksaan Pap Smear Pada Ibu Usia 20-60 Tahun Di Dusun Ngangkrik Triharjo Sleman Tahun 2015, diperoleh hasil sebelum penyuluhan minat pemeriksaan pap smear dalam kategori kurang, setelah penyuluhan diberikan minat dalam kategori baik. Ada beda pretest-postest 10,63 ( $p=0,000)$.

Hasil penelitian yang dilakukan Kurniawati (2014) dengan judul Pengaruh Pengetahuan, budaya dan Dukungan Suami terhadap Perilaku Pemeriksaan IVA pada Wanita Usia Subur di Puskesmas Kedungrejo, diperoleh hasil penelitian ini menunjukkan bahwa ada pengaruh yang positif antara motivasi ibu dengan perilaku melakukan pemeriksaan IVA. Serta ada pengaruh antara dukungan suami dengan perilaku melakukan pemeriksaan IVA

Berdasarkan hasil penelitian adanya beberapa faktor penyebab perilaku kesehatan seperti pengetahuan, 
dukungan suami, peran petugas, ekonomi dan akses ke pelayanan kesehatan. Sehingga walaupun budaya responden positif namun adanya faktor lain yang mempengaruhi perilaku sehingga responden tidak melakukan pemeriksaan IVA.

\section{Dukungan Suami}

Berdasarkan hasil penelitian diketahui responden yang tidak ada dukungan suami sebanyak 69 (70,4\%) responden lebih banyak jika dibandingkan dengan responden yang ada dukungan suami yaitu sebanyak $29(29,6 \%)$ responden.

Sejalan dengan teori menurut Friedman (2014) dukungan keluarga merupakan dukungan berupa informasi verbal, sasaran, bantuan yang nyata atau tingkah laku yang diberikan oleh orang-orang yang akrab dengan subjek didalam lingkungan sosialnya atau yang berupa kehadiran dan hal yang dapat memberikan keuntungan emosional atau pengaruh pada tingkah laku penerimaannya. Dalam hal ini orang yang merasa memperoleh dukungan sosial, secara emosional merasa lega diperhatikan, mendapat saran atau kesan yang menyenangkan pada dirinya.

Hasil penelitian yang dilakukan Kurniawati (2014) dengan judul Pengaruh Pengetahuan, Motivasi dan Dukungan Suami terhadap Perilaku Pemeriksaan IVA pada Wanita Usia Subur di Puskesmas Kedungrejo, diperoleh hasil ada pengaruh antara dukungan suami dengan perilaku melakukan pemeriksaan IVA.

Menurut pendapat peneliti dari hasil penelitian terdapat menunjukkan bahwa dukungan keluarga yang kurang karena kurangnya pengetahuan dari anggota keluarga lain mengenai pelayan kesehatan yang dilakukan oleh keluarganya sendiri. Hal ini sesuai dengan teori bahwa individu membutuhkan dukungan sosial yang salah satunya berasal dari keluarga. Dukungan keluarga yang rendah tersebut disebabkan karena anggota keluarga yang bekerja, sehingga kurang memperhatikan pentingnya pemeriksaan kesehatan dalam upaya pencegahan penyakit.

\section{Dukungan Petugas Kesehatan}

Berdasarkan hasil penelitian diketahui responden yang mengatakan tidak ada dukungan petugas tentang pemeriksaan IVA sebanyak $41(41,8 \%)$ responden lebih sedikit jika dibandingkan dengan responden yang mengatakan ada dukungan petugas kesehatan yaitu sebanyak $57(58,2 \%)$ responden.

Petugas kesehatan adalah seseorang yang bertanggung jawab dalam memberikan pelayanan kesehatan kepada individu, keluarga dan masyarakat. Petugas kesehatan berdasarkan pekerjaannya adalah tenaga medis, dan tenaga paramedis seperti tenaga keperawatan, tenaga kebidanan, tenaga penunjang medis dan lain sebagainya. Ada dua aspek mutu pelayanan kesehatan yang perlu dilakukan di puskesmas yaitu quality of care dan quality of service. Quality of care antara lain menyangkut keterampilan tehnis petugas kesehatan (dokter, bidan, perawat atau paramedis lain) dalam menegakkan diagnosis dan memberikan perawatan kepada pasien (Kemenkes, 2014).

Penelitian yang dilakukan oleh Masturoh (2016) dengan judul Faktor Faktor yang Mempengaruhi Wanita Usia Subur (WUS) dalam Melakukan Deteksi Dini Kanker Serviks dengan Inspeksi Visual Asam Asetat (IVA) di Wilayah Kerja Puskesmas Bangetayu Kota Semarang. Hasil penelitian menunjukkan faktor yang mempengaruhi pemeriksaan kanker serviks adalah dukungan petugas kesehatan $(\mathrm{p}=0,025)$.
Menurut pendapat peneliti peran petugas kesehatan untuk menyadari bahwa pemeriksaan IVA penting bagi Ibu/ WUS merupakan hal yang utama untuk meningkatkan derajat kesehatan dalam pendeteksian dini kanker servik, hal ini dapat menimbulkan perilaku positif ibu/WUS untuk melakukan pemeriksaan IVA. Sikap yang positif akan mempengaruhi perubahan perilaku yang positif. Dengan didasari pengetahuan yang baik dan sikap positif terhadap pemeriksaan IVA, maka ibu/WUS akan berupaya datang ke Puskesmas / posbindu untuk melakukan pemeriksaan IVA yang sangat berguna bagi dirinya.

\section{Hubungan Pengetahuan Dengan Pemeriksaan IVA}

Berdasarkan hasil uji statistik diperoleh p-value $=0$ ,018yang berarti $p>\alpha=0,05$ (Ha diterima dan Ho ditolak), maka dapat disimpulkan bahwa ada hubungan pengetahuan terhadap pemeriksaan IVA di wilayah kerja Puskesmas Karya Tani Labuhan Maringgai Kabupaten Lampung Timur Tahun 2021. Dengan nilai 6,000 berarti responden dengan pengetahuan baik memiliki peluang 6,000 lebih besar untuk melakukan pemeriksaan IVA jika dibandingkan dengan responden dengan pengetahuan kurang baik.

Sejalan dengan teori (Permenkes RI, 2015) Pemeriksaan IVA merupakan pemeriksaan dimana pemeriksanya mengamati serviks yang telah diberi asam asetat/asam cuka 3-5\% secara inspekulo dan dilihat dengan penglihatan mata langsung. Hasil epitel yang abnormal akan berwarna putih, bila semakin putih dan makin jelas makin tinggi derajat kelainan histologinya. Dari pemeriksaan Inspeksi Visual Asam Asetat (IVA) ataupun IVA Test tersebut bila ditemukan keadaan abnormal, maka diperlukan pemeriksaan lebih lanjut didukung dengan pemeriksaan histopatologi sebelum dilakukan pengobatan (S.P Arum, 2015).

Pengetahuan adalah hasil pengindraan manusia, atau hasil tahu seseorang terhadap objek melalui indra yang dimilikinya (mata, hidung, telinga dan sebagainya). Dengan sendirinya pada waktu pengindraan sehingga menghasilkan pengetahuan tersebut sangat dipengaruhi oleh intensitas perhatian dan persepsi terhadap objek (Budiman, 2013).

Sejalan dengan penelitian Endang Mayasari (2017) dari hasil uji statistik diperoleh nilai $\mathrm{p}$ value $=0,027<0,05$ yang artinya ada hubungan antara pengetahuan responden dengan pelaksanaan tes IVA.

Menurut peneliti responden yang tidak melakukan pemeriksaan IVA dapat disebabkan oleh berbagai faktor antara lain akses rumah ke Puskesmas yang sulit terjangkau, tidak adanya biaya, tidak adanya dukungan suami, motivasi yang kurang atau peran petugas yang kurang sehingga walaupun responden memiliki pengetahuan yang baik namun karena tidak adanya faktor pendukung lain maka dapat mempengaruhi perilaku responden untuk melakukan pemeriksaan IVA. Salah satu faktor yang mempengaruhi tingkat pengetahuan adalah informasi. Seseorang yang mempunyai sumber informasi yang lebih banyak akan mempunyai pengetahuan yang lebih luas. Informasi ini dapat diperoleh dari beberapa sumber antara lain televisi, radio, koran, kader, bidan, Puskesmas, majalah. Pengetahun WUS yang tinggi tentang kanker serviks diharapkan dapat merubah sikap dan perilaku untuk deteksi dini kanker serviks dengan melakukan pemeriksaan IVA, sebagaimana diungkapkan pendidikan kesehatan bertujuan menanamkan pengetahuan, dengan harapan agar pengetahuan tersebut dapat membentuk sikap yang pada gilirannya akan membentuk perilaku 


\section{Hubungan Sosial Budaya Dengan Pemeriksaan IVA}

Berdasarkan hasil uji statistik diperoleh p-value $=0,002$ yang berarti $p>\alpha=0,05$ (Ha diterima dan Ho ditolak), maka dapat disimpulkan bahwa ada hubungan sosial budaya terhadap pemeriksaan IVA di wilayah kerja Puskesmas Karya Tani Labuhan Maringgai Kabupaten Lampung Timur Tahun 2021. Dengan nilai OR 7,333 berarti responden dengan sosial budaya positif memiliki peluang 7,333 kali lebih besar untuk melakukan pemeriksaan IVA jika dibandingkan dengan responden dengan sosial budaya negatif.

Sejalan dengan teori (Permenkes RI, 2015) Pemeriksaan IVA merupakan pemeriksaan dimana pemeriksanya mengamati serviks yang telah diberi asam asetat/asam cuka 3-5\% secara inspekulo dan dilihat dengan penglihatan mata langsung. Hasil epitel yang abnormal akan berwarna putih, bila semakin putih dan makin jelas makin tinggi derajat kelainan histologinya. Dari pemeriksaan Inspeksi Visual Asam Asetat (IVA) atau pun IVA Test tersebut bila ditemukan keadaan abnormal, maka diperlukan pemeriksaan lebih lanjut didukung dengan pemeriksaan histopatologi sebelum dilakukan pengobatan (S.P Arum, 2015)

Kebudayaan atau budaya menyangkut keseluruhan aspek kehidupan manusia baik material maupun nonmaterial. Sebagian besar ahli yang mengartikan kebudayaan seperti ini kemungkinan besar sangat dipengaruhi oleh pandangan evolusionisme, yaitu suatu teori yang mengatakan bahwa kebudayaan itu akan berkembang dari tahapan yang sederhana menuju tahapan yang lebih kompleks (Susanto, 2012). Sosial budaya adalah itu sendiri adalah segala hal yang dicipta oleh manusia dengan pemikiran dan budi nuraninya untuk dan atau dalam kehidupan bermasyarakat. Atau lebih singkatnya manusia membuat sesuatu berdasar budi dan pikirannya yang diperuntukkan dalam kehidupan bermasyarakat.

\section{Hubungan Dukungan Suami Dengan Pemeriksaan IVA}

Berdasarkan hasil uji statistik diperoleh p-value $=0,004$ yang berarti $p>\alpha=0,05$ (Ha diterima dan Ho ditolak), maka dapat disimpulkan bahwa ada hubungan dukungan keluarga/suami terhadap pemeriksaan IVA di wilayah kerja Puskesmas Karya Tani Labuhan Maringgai Kabupaten Lampung Timur Tahun 2021. Dengan nilai OR 5,760 berarti responden dengan dukungan keluarga/suami positif memiliki peluang 5,760 kali lebih besar untuk melakukan IVA jika dibandingkan dengan responden dengan dukungan keluarga/suami negatif.

Sejalan dengan teori (Permenkes RI, 2015) Pemeriksaan IVA merupakan pemeriksaan dimana pemeriksanya mengamati serviks yang telah diberi asam asetat/asam cuka 3-5\% secara inspekulo dan dilihat dengan penglihatan mata langsung. Hasil epitel yang abnormal akan berwarna putih, bila semakin putih dan makin jelas makin tinggi derajat kelainan histologinya. Dari pemeriksaan Inspeksi Visual Asam Asetat (IVA) ataupun IVA Test tersebut bila ditemukan keadaan abnormal, maka diperlukan pemeriksaan lebih lanjut didukung dengan pemeriksaan histopatologi sebelum dilakukan pengobatan (S.P Arum, 2015)

Menurut Gottlieb (1983) dukungan keluarga terdiri dari informasi atau nasehat verbal dan nonverbal, bantuan nyata, atau tindakan yang diberikan oleh keakraban sosial atau didapat karena kehadiran mereka dan mempunyai manfaat emosional atau efek perilaku bagi pihak penerima (Bart Smet, Psikologi kesehatan). Dorongan keluarga untuk memberikan perawatan langsung pada setiap keadaan sakit atau sehat. Kepala keluarga (suami) perlu memberikan dukungan moral atau material seluruh anggota keluarga untuk berprilaku hidup sehat (Padila, 2014).

Menurut peneliti terdapat responden dengan ada dukungan suami namun tidak melakukan pemeriksaan IVA. Responden yang tidak memiliki dukungan suami namun melakukan pemeriksaan IVA. Dari hasil penelitian tersebut menunjukkan bahwa dukungan keluarga yang kurang karena kurangnya pengetahuan dari anggota keluarga lain mengenai pelayan kesehatan yang dilakukan oleh keluarganya sendiri. Hal ini sesuai dengan teori bahwa individu membutuhkan dukungan sosial yang salah satunya berasal dari keluarga. Dukungan keluarga yang rendah tersebut disebabkan karena anggota keluarga yang bekerja, sehingga kurang memperhatikan pentingnya pemeriksaan kesehatan dalam upaya pencegahan penyakit

Suami sebagai motivator kuat bagi ibu untuk mengikuti pemeriksaan IVA, sehingga apabila suami dapat menyediakan diri untuk mendampingi, mengantar atau mengingatkan ibu untuk melakukan pemeriksaan IVA maka kesehatan ibu dapat terjaga. Keberadaan anggota keluarga memainkan peranan penting dalam mencegah atau paling tidak menunda orang menderita sakit. Oleh sebab itu, petugas kesehatan perlu mengadakan konseling atau pendidikan kesehatan terhadap keluarga tidak hanya kepada ibu melainkan juga kepada suami sehingga diharapkan melalui hal tersebut meningkatkan pula pengetahuan dan kesadaran keluarga tentang pentingnya peran serta dalam peningkatan kesehatan ibu.

\section{Hubungan Peran Petugas Dengan Pemeriksan IVA}

Berdasarkan hasil uji statistik diperoleh p-value $=0,383$ yang berarti $\mathrm{p}<\alpha=0,05$ (Ho diterima dan Ha ditolak), maka dapat disimpulkan bahwa tidak ada hubungan antara dukungan petugas kesehatan terhadap pemeriksaan IVA di wilayah kerja Puskesmas Karya Tani Labuhan Maringgai Kabupaten Lampung Timur Tahun 2021.

Sejalan dengan teori (Permenkes RI, 2015) Pemeriksaan IVA merupakan pemeriksaan dimana pemeriksanya mengamati serviks yang telah diberi asam asetat/asam cuka 3-5\% secara inspekulo dan dilihat dengan penglihatan mata langsung. Hasil epitel yang abnormal akan berwarna putih, bila semakin putih dan makin jelas makin tinggi derajat kelainan histologinya. Dari pemeriksaan Inspeksi Visual Asam Asetat (IVA) ataupun IVA Test tersebut bila ditemukan keadaan abnormal, maka diperlukan pemeriksaan lebih lanjut didukung dengan pemeriksaan histopatologi sebelum dilakukan pengobatan (S.P Arum, 2015)

Peran petugas kesehatan adalah suatu kegiatan yang diharapkan dari seorang petugas kesehatan yang memberikan pelayanan kesehatan kepada masyarakat untuk meningkatkan derajat kesehatan masyarakat. Petugas kesehatan adalah seseorang yang bertanggung jawab dalam memberikan pelayanan kesehatan kepada individu, keluarga dan masyarakat. Petugas kesehatan berdasarkan pekerjaannya adalah tenaga medis, dan tenaga paramedis seperti tenaga keperawatan, tenaga kebidanan, tenaga penunjang medis dan lain sebagainya. Ada dua aspek mutu pelayanan kesehatan yang perlu dilakukan di puskesmas yaitu quality of care dan quality of service. Quality of care antara lain menyangkut keterampilan tehnis petugas kesehatan (dokter, bidan, perawat atau paramedis lain) dalam menegakkan diagnosis dan memberikan perawatan kepada pasien (UU RI No.38 Th.2014). 
Menurut peneliti terdapat responden mengatakan ada dukungan peran petugas kesehatan namun tidak melakukan pemeriksaan IVA. Responden mengatakan tidak ada dukungan peran petugas kesehatan, namun melakukan pemeriksaan IVA. Menurut pendapat peneliti peran petugas kesehatan untuk menyadari bahwa pemeriksaan IVA penting bagi Ibu/ WUS merupakan hal yang utama untuk meningkatkan derajat kesehatan dalam pendeteksian dini kanker servik, hal ini dapat menimbulkan perilaku positif ibu/WUS untuk melakukan pemeriksaan IVA . Sikap yang positif akan mempengaruhi perubahan perilaku yang positif. Dengan didasari pengetahuan yang baik dan sikap positif terhadap pemeriksaan IVA, maka ibu/WUS akan berupaya datang ke Puskesmas / posbindu untuk melakukan pemeriksaan IVA yang sangat berguna bagi dirinya.

Berdasarkan hasil penelitian dan teori, peneliti berpendapat bahwa sikap petugas kesehatan akan berpengaruh terhadap perilaku pemanfaatan pelayanan kesehatan khususnya pemeriksaan IVA pada ibu/WUS. Para Ibu/WUS tahu bahwa mereka penuh dengan resiko. Salah satunya dari segi kesehatan dan fisik. Pengetahuan ini akan membawa Ibu/WUS untuk berpikir dan berusaha supaya mereka tidak terkena penyakit. Dalam berpikir ini komponen emosi dan keyakinan ikut bekerja sehingga Ibu/WUS berniat datang ke fasilitas kesehatan .

Sikap positif akan membawa dampak Ibu/WUS semakin rajin untuk datang ke pelayanan kesehatan untuk pemeriksaan IVA, sedangkan sikap negatif akan berakibat Ibu/WUS enggan untuk datang ke pelayanan kesehatan untuk pemeriksaan IVA. Peran petugas kesehatan harus lebih ditingkatkan, melalui pelatihan pelayan publik yang diharapkan membantu petugas lebih aktif dan totalitas dalam memberikan pelayanan di kepada ibu/WUS . penyuluhan yang dilakukan oleh petugas, belum secara rutin dilakukan, dan penyuluhan tentang pemeriksaan IVA baru sekali di sampaikan itupun sudah berlangsung lama lebih dari 6 bulan yang lalu.

\section{KESIMPULAN}

Diketahui responden tidak melakukan pemeriksaan IVA yaitu sebanyak $84(85,7 \%)$ responden, pengetahuan baik sebanyak $54(55,1 \%)$ responden, sosial budaya negatif sebanyak $59(60,2 \%)$ responden, dukungan Keluarga/Suami negatif sebanyak $69(70,4 \%)$ responden, dukungan petugas positif sebanyak $57(58,2 \%)$ responden.

Ada hubungan pengetahuan terhadap pemeriksaan IVA di wilayah kerja Puskesmas Karya Tani Labuhan Maringgai Kabupaten Lampung Timur Tahun 2021 ( $p$-value = $0,018, \mathrm{OR}=6,000)$

Ada hubungan sosial budaya terhadap pemeriksaan IVA di wilayah kerja Puskesmas Karya Tani Labuhan Maringgai Kabupaten Lampung Timur Tahun 2021 $(p$-value $=0,002, \mathrm{OR}$ $=7,333$ )

Ada hubungan dukungan keluarga/suami terhadap pemeriksaan IVA di wilayah kerja Puskesmas Karya Tani Labuhan Maringgai Kabupaten Lampung Timur Tahun $2021(p$-value $==0,004, \mathrm{OR}=5,760)$

Tidak ada hubungan antara dukungan petugas kesehatan terhadap pemeriksaan IVA di wilayah kerja Puskesmas Karya Tani Labuhan Maringgai Kabupaten Lampung Timur Tahun 2021 ( $p$-value $==0,383$ )

\section{SARAN}

Bagi WUS
Hasil penelitian ini dapat memberikan pengetahuan untuk ibu tentang kanker serviks, serta rutin melakukan pemeriksaan IVA untuk mencegahan penyakit kanker serviks.

\section{Bagi Peneliti Selanjutnya}

Hasil penelitian ini dapat digunakan sebagai referensi untuk melakukan penelitian yang serupa, ataupun mengembangkan penelitian serupa dengan menambah variable baru.

\section{Bagi Puskemas Karya Tani}

Hasil penelitian ini dapat menjadi masukan untuk petugas kesehatan dalam memperluas sasaran promosi pemeriksaan IVA, tidak hanya kepada ibu saja, namun juga kepada suami atau keluarga agar nantinya juga mendukung untuk melakukan pencegahan terhadap kanker serviks. Penjelasan kepada ibu harus sangat jelas karena dengan motivasi dan saling percaya antara ibu dengan petugas kesehatan mengenai pemeriksaan IVA, maka ibu tidak akan merasa takut atau pun malu.

\section{DAFTAR PUSTAKA}

Arbyn, M., Weiderpass, E., Bruni, L., de Sanjosé, S., Saraiya, M., Ferlay, J., \& Bray, F. (2020). Estimate of incidence and mortality of cervical cancer in 2018: a worldwide analysis. The Lancet Global Health, 8(2), e191-e203. https://doi.org/10.1016/S2214-109X(19)30482-6

Ardayani, T., Tinggi, S., Kesehatan, I., \& Bandung, I. (2020). Hubungan Pengetahuan Dan Dukungan Pemeriksaan Iva Test Pada Wanita Usia Subur Di Puskesmas Ramdhan Kota Bandung Tahun 2020.142-149.

Budiman. (2013). Kapita selekta Pengetahuan dan sikap untuk penelitian kesehatan. Jakarta: Penerbit Salemba Medika.

Dinas Kesehatan Provinsi Lampung. (2020). Profil Kesehatan Provinsi Lampung. Dinas Kesehatan Provinsi Lampung, (44), 302.

Dewi, L., Suryani, N., \& Murdani, P. (2013). Hubungan Tingkat Pengetahuan dan Sikap Wanita Usia Subur (WUS) dengan Pemeriksaan Inspeksi Visual Asam Asetat (IVA) di Puskesmas Buleleng I. Jurnal Magister Kedokteran Keluarga, 1(1), 57-66.

Endang Mayasari. (2017). Faktor-Faktor Yang Mempengaruhi Wanita Usia Subur Yang Tidak Berminat Dalam Pelaksanaan Tes Inspeksi Visual Asam Asetat (IVA) Di Wilayah Kerja Puskesmas Rawat Inap Simpang Tiga Kota Pekanbaru Tahun 2017. Вестник Росздравнадзора, 1 No 2 $\operatorname{tah}(2)$, ISSN 2580-3123.

Friedman, L. M. (2014). Buku Ajar Keperawatan Keluarga Riset, Teori \& Praktik. Jakarta: EGC.

Indonesia, P. R. (2014). Undang Undang Republik Indonesia Nomor 5 Tahun 2014 tentang Aparatur Sipil Negara.

Jumaida, J., Sunarsih, S., Rosmiyati, R., \& Hermawan, D. (2020). Penyuluhan Tentang Kanker Servik Mempengaruhi Pengetahuan Dan Motivasi Pemeriksaan Iva Pada Wanita Usia Subur (Wus). Jurnal Kebidanan Malahayati, 6(1), 104 113. https://doi.org/10.33024/jkm.v6i1.1804

Kemenkes RI. (2016). Panduan Penatalaksanaan Kanker Servik. Kemenkes RI. (2020).

Kemenkes RI. (2020). Profil Kesehatan Indonesia Tahun 2019. In Kementrian Kesehatan Repoblik Indonesia (Vol. 42).

Khodijah. (2014). Psikologi Pendidikan (1st ed.). Jakarta: Rajawali Pres. 
Kurnaesih, E; LIndasari, S.W; Asrina, A. (2018). Prosiding Seminar Nasional 2018 Gambaran Karakteristik Penderita Kanker Serviks Berdasarkan Faktor Resiko Di RSU Sumedang Tahun 2014 Seminar Nasional Sinergitas Multidisiplin Ilmu Pengetahuan dan Teknologi Prosiding Seminar Nasional 2018 Seminar Nasional. 1(April), 23-29.

Kurniawati, I. (2015). Pengaruh pengetahuan, motivasi dan dukungan suami terhadap perilaku pemeriksaan IVA pada kelompok wanita usia subur di Puskesmas Kedungrejo(Doctoral dissertation, UNS (Sebelas Maret University)).

Masturoh, E. (2016). Faktor-Faktor yang Mempengaruhi Wanita Usia Subur (WUS) dalam Melakukan Deteksi Dini Kanker Serviks Metode Inspeksi Visual Asam Asetat (IVA)(Doctoral dissertation, Universitas Negeri Semarang).

Notoatmodjo. (2012). Promosi Kesehatan dan Perilaku Kesehatan. Jakarta: PT. Rineka Cipta.

Notoatmodjo, S. (2018). Metodologi Penelitian. Jakarta: Rineka Cipta.

Padila. (2014). Buku Ajar Keperawatan Keluarga. Yogyakarta : Nuha Medika.

Pebrina, R. J., Kusmiyanti, M., \& Surianto, F. (2019). Faktor Faktor yang Berhubungan dengan Pemeriksaan Inspeksi
Visual Asam Asetat (IVA) di Puskesmas Cibinong Tahun 2019. Jurnal Penelitian Dan Pengembangan Pelayanan Kesehatan, 3(2), 106-113. https://doi.org/10.22435/jpppk.v3i2.2153

Permenkes RI. (2015). Permenkes No 34 tahun 2015 tentang Penanggulangan Kanker Payudara dan Kanker Leher Rahim. 2015. Retrieved from http://weekly.cnbnews.com/news/article.html?no=124000

S.P Arum. (2015). Kanker Serviks: panduan Bagi wanita untuk mengenal, mencegah dan mengobati. Yogyakarta: Sahabat Buku Pintar.

Sepa, F., \& Rusminingsih, R. (2015). Pengaruh Penyuluhan Kanker Serviks terhadap Minat Pemeriksaan PAP Smear Pada Ibu Usia 20-60 Tahun di Dusun Ngangkrik Triharjo Sleman (Doctoral dissertation, STIKES 'Aisyiyah Yogyakarta).

Sugiyono. (2018). Metode Penelitian Kuantitatif, Kualitatif, dan $R \& D$. Bandung: Alfabeta

Wulandari, A., Wahyunigsih, S., \& Yunita, F. (2018). Faktorfaktor yang Berhubungan dengan Perilaku Pemeriksaan Inspeksi Visual Asam Asetat (IVA) pada Wanita Usia Subur (WUS) di Puskesmas Sukmajaya Tahun 2016. Jurnal Kesehatan, 2(2), 93-101. Retrieved from http://ejournals1.undip.ac.id/index.php/jkm\%0AHubungan 